\title{
ARTYKULY
}

Grzegorz Markiewicz

(Uniwersytet Łódzki

Wydział Filozoficzno-Historyczny

Katedra Historii Polski XIX w.)

\section{OPERA JAKO FORMA NARRACJI HISTORYCZNEJ}

$\mathrm{P}$ owstała w drugiej połowie XVI w., we Florencji, grupa skupiająca humanistów, miłośników antyku, kompozytorów i poetów, zwana Cameratą, postawiła sobie za cel badanie kultury antycznej. Podstawowym zadaniem owych pasjonatów starożytności było wskrzeszenie starożytnego greckiego teatru muzycznego. Ponieważ materiałów źródłowych, pozwalających czerpać wiedzę o muzyce antycznej, było niewiele, członkowie Cameraty nie mieli możliwości podjęcia empirycznych badań historycznych, musieli zwrócić się w kierunku teoretyzowania i spekulacji, starając się przełożyć pewien zespół pojęć charakterystycznych dla antyku na kategorie ich własnej kultury. Florentczycy przyjęli założenie, że starożytny dramat grecki był formą śpiewaną, a przynajmniej występował w postaci melodyjnej deklamacji. Starali się zatem dostosować renesansową tradycję muzyczną do wymogów nowego gatunku. Rezultatem był nowy styl muzyczny określany mianem parlar cantando bądź recitativo („mówiony śpiew”, ,śpiewna deklamacja”, „muzyczna recytacja”). Jeden z członków Cameraty, kompozytor pierwszych dzieł operowych, Jacopo Peri pisał w 1600 r., we wstępie do Eurydyki (pierwszego zachowanego dzieła operowego):

Nie ważyłbym się twierdzić, że Grecy i Rzymianie posługiwali się tym stylem śpiewania, doszedłem bowiem do wniosku, że zrodzić go mogła jedynie muzyka naszych czasów, dostosowując go do wymogów naszego języka ${ }^{1}$.

Tak więc już u swego zarania, jak stwierdził Mladen Dolar, opera miota się między odtwarzaniem przeszłości a nowatorstwem² ${ }^{2}$ Muzyczna podróż, jaką odbył Peri, była próbą wniknięcia w kulturę zapomnianej przeszłości. Jej ogląd i interpretacja dokonane zostały z perspektywy kultury badacza ${ }^{3}$. Peri i pozostali członkowie Cameraty, próbując przywrócić światu dramat antyczny, dokonali

\footnotetext{
${ }^{1}$ Cyt. za S. Žižek, M. Dolar, Druga śmierć opery, tłum. S. Królak, Warszawa 2008, s. 16.

${ }^{2}$ Tamże, s. 16.

${ }^{3} \mathrm{Na}$ temat kultury i interpretacji patrz W.J. Burszta, ,My" $i$,oni” - czyli antropologiczne badania nad kultura, [w:] tenże, Wymiary antropologicznego poznania kultury, Poznań 1992, s. 48-49.
} 
translacji kulturowej, a więc podjęli się zadania właściwego historykom i antropologom ${ }^{4}$. Rezultatem owych zabiegów jest opera ${ }^{5}$.

Od samego początku powstania gatunku, dzieła operowe poszukiwały inspiracji w przeszłości. Nieprzypadkowo zwróciły się w kierunku mitologii klasycznej, odgrywając na nowo rytuał odtwarzający mityczne początki naszego społeczeństwa. Widz przestępując progi opery

wchodzi w rolę własnych przodków. Opera nabożnie zatem przywołuje i odtwarza mityczną przeszłość, której, mimo że nikt w nią nie wierzy, wszyscy łakniemy 6 .

Reinhard Strohm zwracał uwagę na fakt, iż przez wieki libretta były najlepszym sposobem zapoznawania Europejczyków z dziedzictwem antycznym, historią i kulturą europejską.

Literackie tworzywa od Homera i Ajschylosa do Cervantesa i Racine'a były wykorzystywane w operze intensywniej i ekstensywniej, aniżeli miało to miejsce gdziekolwiek indziej. Włoska publiczność zapoznawała się z historią i mitami nie tyle dzięki czytaniu literatury, ile na skutek stałego obcowania z teatrem muzycznym

Pochodzące jeszcze z XVI w., pierwsze utwory operowe, skomponowane przez Jacopo Periego i Giulio Cacciniego do libretta Ottavio Rinucciniego inspirowane były losami Dafne ${ }^{8}$ i Orfeusza 9 . Owi bohaterowie, jak i inne mityczne postaci, wypełnią karty siedemnasto - i osiemnastowiecznych librett, żeby

${ }^{4} \mathrm{Na}$ temat relacji między historią i antropologią patrz E. Domańska, Mikrohistorie. Spotkania w międzyświatach, Poznań 1999, s. 63-75.

${ }^{5}$ W Przedmowie do pracy Druga śmierć opery czytamy: „, $[. .$.$] opera urodziła się już martwa,$ była poronionym płodem sztuki muzycznej. Jednym ze standardowych zarzutów stawianych dzisiaj sztuce operowej jest anachroniczność, martwota, a ponadto [...] utrata autonomii, co zmusza ją do pasożytowania na innych sztukach. [...] opera nigdy nie stała w zgodzie ze swym czasem, od samego początku postrzegano ją jako formę przestarzało, zapatrzoną w przeszłość próbę zażegnania endemicznego kryzysu panującego w łonie muzyki, jako sztukę nieczystą. Ujmując rzecz w kategoriach heglowskich - opera była anachroniczna już w samym swym pojęciu" - Przedmowa: Z miłości do opery, [w:] S. Žižek, M. Dolar, dz. cyt., s. 7.

${ }^{6}$ Tamże, s. 14.

${ }^{7}$ R. Strohm, Italienische Opernarien des frühen Settecento, Köln 1976, s. 2. Cyt. za: K. Kozłowski, O libretcie, przemianach w jego rozumieniu i jedności dramatu muzycznego, [w:] tenże, Opera i dramat muzyczny. Szkice, Poznań 2006, s. 10.

${ }^{8}$ Dafne Jacopo Periego i Giulio Cacciniego do libretta Ottavio Rinucciniego, 1597; Dafne Marco da Gagliano do libretta Rinucciniego, 1608; Dafne, Heinricha Schütza, do libretta Martina Opitza, 1627 (Była to pierwsza opera niemiecka, a Schütz jest uważany za ojca opery niemieckiej).

${ }^{9}$ Eurydyka Periego do libretta Rinucciniego, 1600; Eurydyka Cacciniego do libretta Rinucciniego, 1602; Orfeusz Claudio Monteverdiego do libretta Alessandro Striggio Młodszego, 1607. „Aby wszystko było jasne: opera narodziła się 24 II 1607 w książęcym pałacu w Mantui, wraz z prapremierą Orfeusza Monteverdiego. Historyczne znaczenie dzieł Periego i Cacciniego nie zdoła zmienić tego niezbitego faktu" - P. Kamński, Tysiąc i jedna opera, t. 2, Kraków 2008, s. 89. 
przywołać tylko dzieła Claudio Monteverdiego, Jean-Baptiste Lully'ego, Geroga Friedricha Haendla, Jean-Philippe Rameau, Christopha Willibalda Glucka. W wieku dziewiętnastym rzadziej sięgano do klasycznych tematów mitycznych, niemniej powstały takie dzieła jak Medea Giovanni Paciniego do libretta Benedetto Castiglia, Orfeusz w Piekle Jacquesa Offenbacha do libretta Henri Crémieux'a i Ludovica Halévy'ego, Trojanie Hectora Berlioza do libretta kompozytora. Wiek dwudziesty obficie czerpał z mitologii klasycznej, zaś do najwybitniejszych dzieł operowych tego okresu należą: Peleas i Melizanda Claude Debussy'ego do libretta Maurice Maeterlincka, Eros i Psyche Ludomira Różyckiego do libretta Jerzego Żóławskiego, Antygona Arthura Honeggera do libretta Jeana Cocteau, Król Edyp Igora Strawińskiego do libretta Jeana Cocteau, Dafne Richarda Straussa do libretta Josepha Gregora, Antygona oraz Edyp król Carla Orffa do libretta kompozytora.

Barokowa i klasycystyczna opera sporadycznie nawiązywała do mitologii narodowych. Z dzieł, które wytrzymały próbę czasu, wymienić należy Króla Artura Henry Purcella do libretta Johna Drydena, opartego na Histroia Regnum Britanniae Geoffreya z Monmouth. Za to w dziewiętnastym wieku, zainteresowanie rodzimą przeszłością, ginącą w pomrokach dziejów było, głównie za sprawą romantyzmu, ogromne. Liczne wersje eposów germańskich, sag nordyckich, poematów średniowiecznych w języku staroangielskim, starofrancuskim i przekładach niemieckich oraz naukowe opracowania mitologii germańskiej stanowiły fundament oper Ryszarda Wagnera. Do mitologii narodowej odwoływały się takie dzieła jak: Czaromyst ksiąze stowiański Karola Kurpińskiego, Goplana Władysława Żeleńskiego, Rusatka Antona Dvoř́áka, Rogenda Aleksandra Sierowa do libretta Dymitra Awierkijewa. Premiera tego ostatniego dzieła stanowiła jeden z największych triumfów w dziejach opery rosyjskiej. Wystawiona w 1865 r. w Teatrze Maryjskim w Petersburgu, natychmiast uznana została za operę narodową.

Od dzisiaj - pisała krytyka - jutrzenka naszej muzycznej historii datuje się nie od Życia dla cara, lecz od Rogendy ${ }^{10}$.

Sięgano również do ludowych podań i baśni, czego przykładem Kościej nieśmiertelny Nikołaja Rimskiego-Korsakowa (1902) do libretta kompozytora.

Historia, czy jako mythos, czy jako logos, od samego początku była immanentną częścią opery i zadomowiła się w niej na dobre. Być może wynikało to z przekonania, iż jak twierdzi Hermann Lübbe, „historia może jedynie opowiadać”. Zdaniem niemieckiego filozofa

Nauki historyczne - od paleontologii do historii gospodarczej - dawno zamieniłyby się w nauki teoretyczne, gdybyśmy nie byli zainteresowani kulturowo opowiadaniem historii,

${ }^{10}$ Tamże, s. 393. 
które naprawdę się wydarzyły w naturze i społeczeństwie, i które, ze względu na niepowtarzalność zawartych w nich ciągów zdarzeń, nie pozwalają na formułowanie dotyczących ich teorii ${ }^{11}$.

Przypomnę tylko, że do początku dziewiętnastego wieku historiografię uważano za sztukę właściwą sztuce retorycznej. Nowa historiografia zwana narratywizmem ściśle wiąże historiografię z literaturą, podkreślając zarazem, iż historia nie jest obrazem przeszłości. Według Hyden'a White’a dyskurs historyczny jest interpretacją, nadającą uporządkowanej sekwencji zdarzeń „formalną spójność właściwą strukturom fabularnym, występującym w prozie narracyjnej"12. Zajmujący się teorią dyskursu, francuski filozof Paul Ricoeur, jest zdania, iż

nawet najbardziej odległa od narracyjnej formy historia, pozostaje nadal związana z rozumieniem narracyjnym więzią pochodności $(\ldots)^{13}$.

Wedle niemieckiego historyka Jörna Rüsena narracja historyczna to pozbawione obiektywizmu działanie,

za pośrednictwem którego kształtuje się określona świadomość czasu - taka mianowicie, której trzeba przypisać metahistoryczną właściwość, ponieważ bez niej nie można myśleć o intencjonalnym działaniu ludzkich podmiotów w upływie czasu ${ }^{14}$.

Tak rozumiana narracja historyczna bliższa jest dyskursowi poetycko-retorycznemu, niż dyskursowi naukowo-logicznemu ${ }^{15}$.

Amerykański historyk idei Jacques Barzun skonstatował, iż „tak naprawdę to historię można tylko czytać" ${ }^{16}$. White podchwycił tę myśl dodając, iż

historia musi zostać napisana, zanim zostanie przeczytana (czy też opowiedziana, wyśpiewana, wytańczona, zagrana czy nawet sfilmowana) ${ }^{17}$.

Konstatacje Barzuna i White'a odnoszą się do historii rozumianej jako wiedza zgromadzona przez historyków i udostępniona za pośrednictwem historiografii. Ricoeur przekonuje, iż historiografię cechuje strukturalna identyczność z fikcyjną

${ }^{11} \mathrm{H}$. Lübbe, Czym sa historie i po co się je opowiada? Rekonstrukcja odpowiedzi udzielonej przez historyzm, [w:] Opowiadanie historii w niemieckiej refleksji teoretycznohistorycznej i literaturoznawczej od oświecenia do współczesności, wybór, przekład i oprac. J. Kałążny, Poznań 2003, s. 180, 169.

${ }^{12}$ H. White, Proza historyczna, Kraków 2009, s. 32.

${ }^{13}$ P. Ricoeur, Czas i opowieść, t. 1: Intryga i historyczna opowieść, przekład M. Frankiewcz, Kraków 2008, s. 129.

${ }^{14}$ J. Rüsen, Cztery typy narracji historycznej, [w:] Opowiadanie historii w niemieckiej refleksji teoretycznohistorycznej..., s. 502.

${ }^{15}$ Cyt. za: H. White, dz. cyt., s. 11.

${ }^{16}$ Tamże, s. 21

${ }^{17}$ Tamże, s. 22. 
opowieścią ${ }^{18}$. Obie, podkreśla filozof, są różnymi sposobami narracji ${ }^{19}$. Historiografia pisze historię, która, jak twierdzi Lübbe, opowiada o faktach. Podobnie jest z operą, będącą jednym z najbardziej złożonych gatunków artystycznych, ponieważ łączy w sobie cechy utworu literackiego, dramatycznego i muzycznego, które przejawiają się w postaci libretta, muzyki i dramatu ${ }^{20}$. Opera pisze i opowiada historię. Słowo zawarte w libretcie nadaje historii sens, muzyka zapisana w partyturze oddaje uczucie, inscenizacja jest wizualną formą wyrazu afektów zawartych w libretcie i muzyce. Libretto, partytura i inscenizacja, każde z osobna, są interpretacją zdarzeń. Zależność, wzajemne przenikanie się tych trzech części składowych, tworzy nową interpretację, która zdarzeniom nadaje formę spójności właściwą strukturom fabularnym, zaś każda inscenizacja, przekształcając kody sceniczne, jest kolejną interpretacją ${ }^{21}$.

Takie właśnie nadawanie kronice zdarzeń struktury fabularnej - twierdzi White - przeprowadzane jest przy pomocy technik dyskursywnych o charakterze bardziej tropologicznym niż logicznym ${ }^{22}$.

Teoria tropów White’a zakłada, iż opowieść o przeszłości wykorzystuje cztery tropy: metaforę (opartą na zasadzie podobieństwa), metonimię (opartą na zasadzie zgodności), synekdochę (opartą na relacji części do całości) oraz ironię (opartą na przeciwieństwie $)^{23}$. Tym czterem typom tropów, odpowiadają cztery typy fabuł, na których opierają się dzieła operowe: romans, tragedia, komedia i satyra ${ }^{24}$.

Historia od chwili narodzin opery, stanowiła jeden z jej głównych zakresów tematycznych, jednak nie ona była wątkiem dzieła, ale intryga. Historia była osnową. Autorzy librett, mimo iż niejednokrotnie sięgali do źródeł historycznych, czego wzorcowym przykładem był Wagner, często przeinaczali, modyfikowali lub wręcz fałszowali zdarzenia historyczne, zaś postaci historyczne nader rzadko

${ }^{18}$ Patrz P. Ricoeur, $d z$. cyt., s. 127-304. P. Ricoeur, Czas i opowieśśc, t. 2: Konfiguracja w opowieści fikcyjnej, Kraków 2008.

${ }^{19}$ P. Ricoeur, Czas i opowieść, t. 3: Czas opowiadany, przekład U. Zbrzeźnak, Kraków 2008.

${ }^{20} \mathrm{Na}$ temat relacji między słowem, muzyką i dramatem w operze patrz J. Mianowski, Krzywe lustro opery, Torun 2011, s. 9-25.

${ }^{21}$ Wielu kompozytorów próbowało bronić się przed jakąkolwiek interpretacją. W tym celu bardzo szczegółowo opisywali swe partytury. Igor Strawiński był zdania, że: „Muzyka bowiem powinna być przekazywana, a nie interpretowana [...]. Gdy interpretacja odstania raczej osobowość interpretatora niż kompozytora, któż nam może zagwarantować, że wykonawca odda bez znieksztatcenia obraz twórcy? I dodaje gdzie indziej: Interpretator bowiem, niestety może myśleć tylko o interpretacji zalicza sie przez to do thumacza (traduttore-traditore), co w muzyce jest absurdem, a dla interpretatora - źródtem próżności, która prowadzi nieuchronnie do najśmieszniejszej megalomanii” - I. Strawiński, Kroniki mojego życia, tłum. J. Kydryński, Kraków 1974, s. 74-75.

${ }^{22}$ H. White, $d z$. cyt., s. 32.

${ }^{23}$ Tamże, s. 37.

${ }^{24}$ Tamże, s. 38. 
przedstawiali pozostając w zgodzie z przekazami źródłowymi. Postaci historyczne wpisywane były $\mathrm{w}$

fabułę, odwołującą się mniej lub bardziej wiernie do wydarzeń także znanych odbiorcom bądź ze szkoły, bądź z lektury, ale uproszczoną, wystylizowaną i dostosowaną do specyfiki wymagań gatunku, jakim jest libretto operowe ${ }^{25}$.

Narracja historyczna w dziele operowym, jak każda narracja historyczna, odwołuje się do teraźniejszości,

mobilizuje więc pamięć w taki sposób, że przechowywane w niej doświadczenia przeszłości czynią zrozumiałymi doświadczenia teraźniejszości² ${ }^{26}$.

W efekcie na przestrzeni dwustu lat, w każdej epoce, każda publiczność oglądała takiego Aleksandra Wielkiego, jaki był jej potrzebny i jaki najlepiej odzwierciedlał jej dążenia, idee, koncepcje ${ }^{27}$. Deformacja prawdy historycznej posunięta bywa w operach do tego stopnia, iż korzystają one tylko z wybranych epizodów, które mają przemówić i stać się zrozumiałe, dla publiczności ${ }^{28}$. Francuski archeolog i historyk Paul Veyne jest zdania, iż historia

poszukuje tylko prawdy, nie jest więc nauką, która poszukuje ścisłości. Nie narzuca żadnych norm, nie kierują nią żadne reguły, nic nie jest dla niej niedopuszczalne [...] jeśli tylko relacja jest zgodna $\mathrm{z}$ prawdą, historia jest zadowolona ${ }^{29}$.

Pozostaje pytanie, jak daleko w dziele operowym może być dokonana deformacja prawdy historycznej, żeby mimo to, historia była zadowolona? Arystoteles twierdził, iż

nie wolno poecie dowolnie przekształcać przekazanych przez tradycję mitów, jak np. faktu, że Klitajmestra została zabita przez Orestesa (...), powinien on jednak wykazać się pomysłowością i w sposób artystyczny wykorzystać tradycyjny materiał ${ }^{30}$.

Dziewiętnastowieczny, niemiecki teoretyk dramatu Gustaw Freytag podkreŚlał, iż:

${ }^{25}$ A. Klęczar, Che il valor d'Alessandro e la fortuna. Aleksander Wielki jako bohater opery, [w:] Opera wobec historii, red. R.D. Golianek, P. Urbański, Torun 2012, s. 45.

${ }^{26}$ J. Rüsen, Cztery typy narracji historycznej, [w:] Opera wobec historii, s. 504.

${ }^{27}$ A. Klęczar, Che il valor d'Alessandro e la fortuna. Aleksander Wielki jako bohater opery, [w:] Opera wobec historii, s. 51.

${ }^{28}$ A. Ryszka-Komarnicka, Między argomento storico, operowa fikcja, [w:] Opera wobec historii, s. 85 .

${ }^{29}$ Cyt. za: H. White, dz. cyt., s. 23.

${ }^{30}$ Arystoteles, Poetyka, 1453b20-23, thum. H. Podbielski, Retoryka. Retoryka dla Aleksandra. Poetyka, Warszawa 2009. 
Publiczność przychodzi do teatru z pewnym zapasem wiadomości i wyobrażeń, które poeta musi uwzględnić, jeśli się nie chce narazić na zarzut nieprawdopodobieństwa. Każdy przeciętny wiedz posiada np. elementarną znajomość geografii i historii, i był w życiu mniej więcej uważnym obserwatorem. Gdy więc poeta każe okrętom dobijać do brzegów czeskich, lub wojskom Karola Wielkiego strzelać z armat, nie może liczyć na wiarę ${ }^{31}$.

Francuski lekarz, literat, dramaturg Hippolyte-Jules Pilet de La Mesnardière, jedna z głównych postaci pracujących w drugiej połowie XVII w. nad kodyfikacją klasycznego dramatu francuskiego, był zdania, iż poeta powinien kierować się rozsądkiem. Nie może on sprawić, że Orestes nie zabije Kiltajmestry, nie powinien jednak zbyt drobiazgowo przywiązywać się do przedstawianych zdarzeń.

Historia twierdzi, że Cezar został zabity w senacie i że od chwili otrzymania ciosu, aż do oddania ducha, nie wyrzekł więcej niż trzy słowa. Byłoby wielkim uchybieniem kazać temu władcy umrzeć we własnym pałacu, w ramionach Kalpurni. Jednak nie zgrzeszyłoby się przeciwko prawidłom teatru, przyjmując, że Cezar powiedział do Brutusa więcej, niż podają historycy. Tym bardziej, że nie jest niemożliwym, by przed ostatnim tchnieniem zamordowana osoba wypowiedziała dwadzieścia czy trzydzieści słów, natomiast pozostaje niepojętym, by historia omyliła się w określeniu miejsca śmierci tak wielkiego władcy ${ }^{32}$.

\section{Jak podkreślił Michał Bajer, Mesnardière poszukiwał w ten sposób}

kompromisu między rygorystycznym powiązaniem tragedii z historią a daleko idącym uniezależnieniem poezji od kronikarskiego przekazu ${ }^{33}$.

Kompromis był często konieczny także ze względu na obowiązującą konwencję. Przykładem jest mit orficki, który twórcy operowi szczególnie chętnie podejmowali. Z jednej strony nie było takiej możliwości, żeby zrozpaczony Orfeusz nie zszedł pod ziemię po ukochaną małżonkę. $Z$ drugiej strony opera seria musiała mieć szczęśliwe zakończenie, w związku z czym Orfeusz musiał albo powrócić z Eurydyką na ziemię, jak to jest w przypadku Eurydyki Jacopa Periego do libretta Ottavio Rinucciniego (1600), Orfeusza i Eurydyki Christopha Wilibalda Glucka do libretta Ranieriego de Calzabigi (1762), albo przynajmniej mieć możliwość obcowania z nią wśród gwiazd, jak to jest u Orfeusza Claudio Monteverdiego do libretta Alessandro Striggio Młodszego (1607) i Orfeusza Luigi Rossiego do libretta Francesco Butiego (1647). Z tej konwencji szczęśliwego połączenia pary małżonków wyłamuje się, pozostając w zgodzie z mitem, Orfeusz albo Cudowna statość w miłości Georga Philippa Telemanna do libretta nieznanego poety (1736),

${ }^{31}$ T.J. Choiński, Technika dramatu. Podtug Gustawa Freytaga Die Technik des Dramas, „Echo Muzyczne Teatralne i Artystyczne" 1887, nr 211.

32 J.H. Pilet, L.A. Mesnardiere, Poetyka, [w:] Trzy poetyki z czasów Richelieu, thum. i oprac. M. Bajer, Gdańsk 2010, s. 65.

${ }_{33}$ M. Bajer, Historyczne exemplum $w$ operze włoskiej i francuskiej pierwszej połowy XIX $w$., [w:] Opera wobec historii, s. 348. 
pozostawiając Eurydykę nieodwołalnie w czeluściach piekieł, zaś Orfeusza rozrywając na strzępy przez oszalałe bachtanki. Podobnie dzieje się w Duszy filozofa albo Orfeusz i Eyrydyka Franza Josepha Haydna do libretta Carlo Francesco Badiniego (skomponowana w 1791, wystawiona dopiero w 1950) z tym, że zamiast rozszarpać poetę, bachtanki zmuszają go do wypicia trucizny. Oczywiście nie można nie wspomnieć o Orfeuszu w Piekle Jacquesa Offenbacha do libretta Henri'ego Crémieuxa i Ludovica Halévy'ego (1858). Opera ta poszła pod prąd mitologii łamiąc jednocześnie wszelkie ówczesne konwenanse i konwencje. Wywołała skandal, została przeklęta i stała się arcydziełem sztuki operowej. Tyle tylko, że w tym przypadku twórcy nie mieli zamiaru ani podważać mitu, ani odwoływać się do historii.

Żyjący w tym samym czasie co Mesnardière, pisarz i duchowny François Hedelin d'Aubignac był zdania, iż poecie należy dać całkowitą swobodę dysponowania materiałem historycznym, może on zmieniać historię

nie tylko względem okoliczności, ale również w głównym działaniu, jeżeli tylko ułoży piękny utwór. Gdyż tak samo jak nie zatrzymuje się on na czasie - ponieważ nie zajmuje go chronologia - nie przywiązuje się również do prawdy, podobnie jak poeta epicki, ani jeden, ani drugi bowiem nie są historykami. Biorą z historii to, co dla nich właściwe, i zmieniają pozostałe rzeczy, aby uczynić z tego swoje utwory. I jest pociesznym pomysłem, żeby udawać się do teatru w celu poznania historii ${ }^{34}$.

Wspomniany już Freytag przekonywał, że:

Inaczej myśli uczony, a inaczej poeta. Uczonemu idzie głównie o prawdę bezwzględną, artysta zaś zadawala się prawdopodobieństwem. Gdy historyk wybierze do studiów swoich jakiego męża rozgłośnego, lub jaką epokę, wtedy stara się przede wszystkim o skonstatowanie faktów. Udowodnienie: jak coś było? jest jego zadaniem i celem. Odpowiedź na pytanie: jak mogło, lub powinno być? nie należy do niego. Poecie nie wystarczają dane rzeczywiste. Najdrobniejszy wypadek, przybiera w jego głowie rozmiary monstrualnego obrazu, tworzącego całość jednolitą. Czego nie dało życie, to dopełnia jego wyobraźnia. $(. . .)^{35}$.

Przywołany przeze mnie już wcześniej literaturoznawca i thumacz Michał Bajer, odwołując się do teoretycznych rozważań na temat stosunku dzieła poetyckiego do historii, snutych przez Pierre Corneille i Jeana Racine, podaje przykłady oper, które trzymają się ściśle wyznaczonych przez owych poetów reguł. Pierre Corneille był zdania, że

o ile tylko zachowamy skutki znane z historii, o tyle wszelkie okoliczności, albo jak je nazywam, ścieżki do nich prowadzące są w naszej mocy ${ }^{36}$.

${ }^{34}$ F. Hedelin d'Aubignac, Poetyka teatru, [w:] Trzy poetyki..., s. 133.

${ }^{35}$ T.J. Choiński, $d z$. cyt.

${ }^{36}$ P. Corneille, Préface a ,Rodogune”, [w:] tenże, Euvres complètes, oprac. A. Stegmann, t. 2, Paris 1984, s. 197. Cyt za: M. Bajer, dz. cyt., s. 349. 
O ścieżkach prowadzących do zdarzeń - twierdził poeta

historia często nic nie mówi, bądź też wspomina tak skąpo, że chcąc wypełnić utwór, koniecznie trzeba uzupełnić to milczenie. Zdaje się nawet, że pamięć słuchacza [tj. widza] znającego je [te okoliczności historii] z minionych lektur nie przywiąże się do nich na tyle silnie, by spostrzegł on wprowadzone zmiany i oskarżył nas o kłamstwo, co też uczyniłby niechybnie, widząc, że zmieniliśmy działanie główne ${ }^{37}$.

U Corneille'a - twierdzi Bajer -

zgodne z prawdą historyczną zdarzenie mieści się głównie w funkcji katastrofy i tragediopisarz dopisuje doń swoistą fikcyjną ,"prehistorię"38.

Schemat ten odnaleźć można w dziewiętnastowiecznych operach, takich jak: Ostatni dzień Pompei Giovanniego Paciniego do libretta Andrea Leone Tottoli (1825); Wilhelm Tell Gioacchino Rossiniego do libretta Victora Josepha Etienne de Jouy'ego i Hippolyte'a Louisa Florent'ea Bis (1829); Oblężenie Calais Gaetano Donizettiego do libretta Salvatore Cammarano (1836); Horacjusze i Kuriacjusze Giuseppe Saverino Mercadantego do libretta Salvatore Cammarano (1846); Bitwa pod Legnano Giuseppe Verdiego do libretta Salvatore Cammarano (1849); Nieszpory sycylijskie Verdiego do libretta Augustina Eugene Scribe'a i Charles'a Duveyrier'a (1855); Hugenoci Giacomo Meyerbeera do libretta Scribe'a i Emille Deschampsa ${ }^{39}$. W odmienny od Corneille'a sposób, przywoływał historię Jean Racine. Polegał on „na obieraniu historycznego punktu wyjścia, wiodącemu ku niehistorycznemu rozwiązaniu intrygi" ${ }^{40}$. Regułę tę można odnaleźć w operach Joanna d'Arc (1845) i Attylla (1846) Verdiego do libretta Temistocle'a Solery. W obu wypadkach prawdziwe jest tło, czyli konflikt angielsko-francuski i najazd Hunów na Italię, fikcyjnymi zaś są okoliczności śmierci tytułowych bohaterów. I o ile śmierć Attyli na skutek dokonanego nań zamachu wydaje się być bardziej zgodna z logiką intrygi i wymaganiami widowiska, niż oddanie ostatniego tchu na skutek krwotoku z nosa, o tyle śmierć Dziewicy Orleańskiej w czasie bitwy przeczy już nie tylko faktom ale i burzy całą legendę związaną z tą katolicką świętą, patronką Francji i konfliktem francusko-angielskim. Przyczyny takiego zakończenia, twierdzi Bajer, są

po części związane z politycznym znaczeniem dzieła. Okupowana przez wrogie wojska Francja doby wojny stuletniej staje się tu ekranem, na którym Solera i Verdi projektują problemy współczesnych Włoch. W tej sytuacji polityczne zawiłości, które w historii doprowadziły do stracenia męczennicy, stanowią zbędny balast ${ }^{41}$.

\footnotetext{
${ }^{37}$ P. Corneille, $d z$. cyt., s. 159. Cyt za: M. Bajer, $d z$. cyt. s. 349.

${ }^{38}$ Tamże, s. 350.

${ }^{39}$ Tamże.

${ }^{40}$ Tamże.

${ }^{41}$ Tamże, s. 352.
} 
Bajer zwraca również uwagę, na jego zdaniem ważniejsze od politycznych, względy formalne, które powodowały, iż obowiązujący wówczas kod sceniczny, nakazujący wprowadzenie solowej sceny pożegnania bohatera, który następnie udaje się na miejsce kaźni usytuowane za sceną, czyniłyby takie rozwiązanie banalnym ${ }^{42}$.

Niewątpliwie charakterystyczna dla danej epoki konwencja operowa oraz kody sceniczne, krępowały swobodę twórców operowych w prezentowaniu zdarzeń historycznych w zgodzie ze źródłowym przekazem. Pamiętajmy, że libretto to tekst przeznaczony do umuzycznienia, co wpływa na jego formę dramaturgiczną i leksykalną ${ }^{43}$. I pomimo, że podstawowa cecha opery - wykonywanie wszystkich partii przy pomocy śpiewu - stanowiła prymarny i niepodważalny wyznacznik gatunku, którego nie mogły zmienić estetyczne priorytety żadnej z epok, to jednak forma dramatyczna dominowała nad formą muzyczną, a tekst był czynnikiem najważniejszym. Przypomnę tylko, że do drugiej połowy XVIII w. rzadko używano terminu opera, najczęściej posługiwano się pojęciem dramma per musica, co miało podkreślać, iż dzieło nie jest standardowym tekstem dramatycznym, ale dramatem muzycznym. Wynikało to, jak twierdzi Hanna Wniszewska, z wyższego statusu poezji i słowa pisanego $\mathrm{w}$ ogóle ${ }^{44}$. Tak było przynajmniej do pierwszej połowy XIX w.

Ten literacki charakter ówczesnej opery odczytujemy dziś nie tylko z teoretycznych rozpraw, lecz także z faktu, że tytuł opery poniekąd zrastał się wówczas z nazwiskiem autora tekstu, a nie muzyki, mówiono zatem i pisano o operach Ludwika Dmuszewskiego, Juliana Ursyna Niemcewicza, Jana Nepomucena Kamińskiego, Kazimierza Brodzińskiego ${ }^{45}$.

Konwencjonalizacja słowna nakazująca zaopatrywać libretto w słowa-klucze o charakterze wyraźnie emocjonalnym, niewątpliwie ograniczała możliwości w kreśleniu sylwetek postaci historycznych.

Rola afektów - podkreśla Jarosław Mianowski - w tak skonstruowanym libretcie jest zasadnicza i determinuje jego kształt. Te barokowe kategorie emocjonalne zdominowały myślenie o operze w XVII i XVIII wieku.

Co więcej nieznajomość konwencji jaka obowiązywała w epoce baroku i klasycyzmu, powoduje niewłaściwe odczytanie przekazu emocjonalnego, towarzyszącego przedstawianym bohaterom. Bowiem

${ }^{42}$ Tamże.

${ }^{43}$ Patrz: J. Mianowski, Krzywe lustro opery, Torun 2011, s. 11.

${ }^{44}$ H. Wniszewska, Dramma eroicomico, czyli deheroizacja historii, [w:] Opera wobec historii, s. 171.

${ }^{45}$ E. Nowicka, „Stownik zaklętych stów do muzyki” (o librettach oper Józefa Elsnera i Karola Kurpińskiego, [w:] Opera polska w XVIII i XIX wieku, red. M. Jabłoński, J. Stęczewski, J. Tatarska, Poznań 2000, s. 50. 
wśród afektów pozytywnych (affectus iucundi) wymieniano amor (miłość), spes (nadzieję), fiduzia (ufność), gloria (chwałę), ale i odium (nienawiść), irrisio (szyderstwo) czy cupiditas vendicatae (żądzę zemsty). Z kolei jako afekty negatywne (affectus molesti) rozumiano między innymi commiseratio (współczucie, litość), invidia (zazdrość), metus (lęk), desperatio (rozpacz)...46.

Dziewiętnastowieczna konwencja dramatu nakazywała, iż

bohater dramatyczny, musi ludzi przeciętnych przewyższać o całą głowę. Musi on chcieć czegoś niecodziennego, musi czuć głębiej i silniej, niż pospolity filister. [...] W największym zbrodniarzu dramatycznym tkwią resztki wielkiej indywidualności. Może on być potworem, ale potworem niezwykłym. Marny tchórz, tracący przytomność wobec niebezpieczeństwa, nikczemnik, zginający się w łęk przed siłą, kwalifikują się przed kratki sądowe. W dramacie nie ma dla nich miejsca ${ }^{47}$.

Wspomniana powyżej rola afektu w operze XVII i XVIII w. sprawiała, że historia, która wkroczyła na scenę wraz z dziełem Claudia Monteverdiego i Giovanni Francesco Busenellego Koronacja Poppei (1643), miała charakter koturnowy i heroiczny. Taka zresztą była właściwość gatunku, określonego później mianem opery seria. Opery tego typu, były operami heroicznymi, potrzebowały bohaterów nieprzeciętnych, o niepospolitych charakterach, dlatego sięgano do postaci historycznych, których czyny oddziaływały na szersze kręgi społeczne ${ }^{48}$. Opery heroiczne prezentowały władców z jednej strony uwikłanych w historię, z drugiej stojących przed osobistym wyborem natury moralnej lub etycznej, wstrząsanych namiętnościami, niewolnych od słabości i wad, czasami wręcz z gruntu amoralnych i zepsutych ${ }^{49}$, ale też i takich, którzy śmiało stawiali czoło przebiegłym wrogom, kierowali się poczuciem honoru i sprawiedliwości $i^{50}$, lub też przepełnieni byli wielkodusznością i skłonnością do wybaczania ${ }^{51}$. Na ogół obowiązywała zasada, iż władca musiał stać ponad swymi poddanymi również w sensie moralnym. Opera seria była bowiem lustrzanym odbiciem dworskiego towarzystwa i w wielu przypadkach mecenas dzieła i właściciel teatru siedział na widowni.

\footnotetext{
${ }^{46}$ J. Mianowski, $d z$. cyt., s. 11-12.

${ }^{47}$ T. J. Choiński, dz. cyt., nr 212.

${ }^{48}$ Tamże.

${ }^{49}$ Taka jest ociekająca krwią i przepełniona podłością Koronacja Poppei, gdzie nie ma pozytywnych bohaterów, ponieważ nawet Seneka „okazuje się też z lekka nadętym osłem ( Ecco la sconsolata»), zadającym szyku pustosłowiem i moralistyką dla ubogich” - D. Czaja, Trucizna miłości, „dwutygodnik.com" 2012, nr 84 (dostęp 22 VIII 2014).

${ }^{50}$ Za szczytowe osiągnięcie opery seria uchodzi Juliusz Cezar w Egipcie Georga Friedricha Haendla do libretta Nicola Hayma (1724). Zdarzały się też opery określane dziś mianem antyheroicznych jak dzieło Georga Friedricha Haendla i Vincenzo Grimaniego Agrypina (1709).

${ }^{51}$ Laskawość Tytusa Wolfganga Amadeusza Mozarta i Caterino Tommaso Mazzoli (1791).
} 
Deheroizacja historii następuje wraz z pojawieniem się w XVIII w. dramma eroicomico (opery heroikomicznej), parodiującej koturnowy styl opery seria. Dotychczasowi herosi okazali się zwykłymi ludźmi, Kserkses opiewa zalety cienistego drzewa, Chan Kubilaj miota się w sieci błahych intryg dworskich, piraci śmieją się z pogróżek Juliusza Cezara ${ }^{52}$. Historia jest tu tłem dla snucia opowieści o rzeczach przyziemnych.

Z końcem osiemnastego wieku, gdy zaczynają się kształtować idee rewolucyjne i narodowe, znajdą one odzwierciedlenie także w operze. Gatunek zwany operą rewolucyjną, wprowadza na scenę rewolucję niesioną przez tłum, który jest narzędziem makrohistorii [Ferdinando Paer (1771-1839), Joseph Mehl (1763-1817), Luigi Cherubini (1760-1842), Jean-François Leseur (1760-1837) i Nicolas-Marie d'Alayrac (1753-1809)]. Temat poruszany później od Niemej z Portici Aubera (1828) po Siemiona Kotko Prokofiewa (23 VI 1940).

W wieku XIX nastąpił rozkwit gatunku zwanego operą narodową, aczkolwiek jego początki sięgają osiemnastego wieku. W operze Günther z Schwarzburga Ignaza Holzbauera, wystawionej w 1785 r. w Mannheim, ukazany został ideał niemieckiego władcy. Tematyka dzieła oparta została na wątkach z historii czternastowiecznego sporu o koronę cesarską między Karolem Luksemburskim a rodem Wittelsbachów. Librecista Anton Klein pisał w przedmowie do opery:

Czyż niemieccy bohaterowie, którzy zasługują na to, by stali się przykładem dla kolejnych ludzkich pokoleń, mieli zostać zapomniani w swojej własnej ojczyźnie? Czy tylko popioły Rzymu i Aten godne są upamiętnienia? [...] Kierujemy nasze oczy na obce wzory, które prawdopodobnie nigdy nie istniały, a nie widzimy tego, co sami posiadamy w łonie [naszej historii]. [...] Dlatego tez wybrałem jednego z naszych najznamienitszych bohaterów. [...] To ojczyzna stanowiła cel [jego życia]. Z miłości do ojczyzny włożył on koronę i z miłości do ojczyny ją oddał ${ }^{53}$.

Klasycznym przykładem opery narodowej, odwołującej się do historii, jest Życie za cara Mikołaja Glinki i libretta zbiorowego autorstwa (1836), grana także pod tytułem Iwan Susanin. Opera ta była wznawiana na scenie rosyjskiej w przełomowych momentach historycznych i okresach patriotycznych uniesień. Aż do przewrotu bolszewickiego co roku otwierała sezon operowy. W 1924 r. wystawiono ją w Odessie i Baku pod tytułem Sierp i młot. W 1939 r. w Moskwie pod tytułem Iwan Susanin, czyniąc, zgodnie z panująca ideologią, reprezentanta ludu tytułowym bohaterem. W finałowej apoteozie wprowadzono nieme postacie księcia Dmitrija Pożarskiego oraz kupca Kuźmy Minina jako personifikacje arystokracji i mieszczaństwa, symbolizujące jedność narodu ponad podziałami

${ }^{52}$ H. Wniszewska, dz. cyt., s. 165.

${ }^{53}$ A. Klein, Wstęp do opery Günther von Schwarzburg, Mannheim 1777 (rękopis przechowywany w zbiorach berlińskiej Staatsbibliothek Preubischer Kulturbesitz, sygn. Mus. Ms 10780). Cyt. za: M. Nahajowski, Gunter z Schwarzburga. Ideat niemieckiego wtadcy w operze Holzbauera, [w:] Opera wobec historii, s. 206. 
klasowymi, solidarnie występującego przeciwko najeźdźcom. Ta wersja obowiązywała w Rosji aż do 1989 r., kiedy to przywrócono oryginał. Dla Czechów dziełem narodowym byli Brandenburczycy w Czechach Bedřicha Smetany i Karela Sabina (1866). Na Węgrzech takiego znaczenia nabrał Hunyadi Laszlo (1844) i Bank Ban (1861) oba autorstwa Ferenca Erkeal i Beni Egressy'ego (1844).

W operze znalazł również odzwierciedlenie jeden z nurtów współczesnej historiografii - mikrohistoria. Nurt ten skupia się na historycznym badaniu niewielkich przestrzeni zarówno terytorialnych jak i czasowych. Uwaga badacza skoncentrowana jest na życiu codziennym społeczności lokalnych, na ich świadomości, obyczajach, namiętnościach. Tego typu operowe narracje odwołujące się do ludzkiej religijności i seksualności możemy odnaleźć w Dialogach Karmelitanek Francisa Poulenca (1957), których fabuła nawiązuje do autentycznego wydarzenia, jakim było uwięzienie i stracenie w czasie rewolucji francuskiej (17 VII 1794) zakonnic z klasztoru Karmelitanek w Compiegne, uznanych w 1907 r. za katolickie błogosławione. Podobnie jest z operą Krzysztofa Pendereckiego Diabły z Loudun (1969) relacjonującą widzowi autentyczne wydarzenia z początku XVII w. w Loudun we Francji, gdzie odbył się proces księdza Urbana Grandiera, oskarżonego przez przeoryszę klasztoru Urszulanek o opętanie zakonnic i konszachty z diabłem.

Podsumowując należy stwierdzić, iż historia towarzyszy operze od samych początków tego gatunku muzyczno-scenicznego. Dzieła operowe opowiadają historię, która zasadniczo pozostaje w zgodzie z prawdą. Do XIX w. opera była jedną z głównych artystycznych form przekazu dziejów. Przekaz ten był bliższy antropologii historycznej niż historii.

\section{Grzegorz Markiewicz}

\section{THE OPERA AS THE FORM OF THE HISTORICAL NARRATION}

In the second half the $16^{\text {th }}$ century, in Florence, group gathering specialists in the arts, enthusiasts of the antiquity, composers and poets, called Camerata, put examining the ancient culture for herself behind the target. Resurrecting an ancient Greek musical theatre was a basic task of those fans of the antiquity. An opera is a result of those treatments. From very beginning of the creation of the kind, operatic work sought the inspiration in the past. At first they referred to the classical mythology. Then to medieval history and modern history and national mythology. For centuries librettos were the best way of acquainting Europeans with the ancient legacy, history and the European culture. New historiography is combining historiography with literature, emphasizing all at the same time that history isn't an image of the past. According to Hyden Whte the historical discourse is interpretation. Paul Ricoeur is convincing that a structural sameness is characterizing historiography with the fictional story. One and second are different ways of the narration. Historiography is writing the story which is talking about facts. Similarly is with the opera, being one of the most compound artistic kinds, since is combining features of the, dramatic and musical literary work which manifest itself in the form of the libretto, the music and the drama. Opera is writing and telling a story. 